\title{
Contes, éd. crit. Raymonde Robert
}

\section{Daniela Dalla Valle}

\section{(2) OpenEdition}

\section{Journals}

\section{Edizione digitale}

URL: http://journals.openedition.org/studifrancesi/33152

DOI: 10.4000/studifrancesi.33152

ISSN: 2421-5856

\section{Editore}

Rosenberg \& Sellier

\section{Edizione cartacea}

Data di pubblicazione: 1 décembre 2005

Paginazione: 637

ISSN: 0039-2944

\section{Notizia bibliografica digitale}

Daniela Dalla Valle, «Contes, éd. crit. Raymonde Robert», Studi Francesi [Online], 147 (XLX | III) | 2005,

online dal 01 novembre 2015, consultato il 18 avril 2021. URL: http://journals.openedition.org/ studifrancesi/33152 ; DOI: https://doi.org/10.4000/studifrancesi.33152

\section{Questo documento è stato generato automaticamente il 18 avril 2021.}

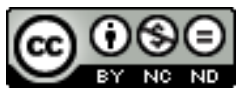

Studi Francesi è distribuita con Licenza Creative Commons Attribuzione - Non commerciale - Non opere derivate 4.0 Internazionale. 


\title{
Contes, éd. crit. Raymonde Robert
}

\author{
Daniela Dalla Valle
}

\section{NOTIZIA}

MADEMOISELLE LHÉRITIER, MADEMOISELLE BERNARD, MADEMOISELLE DE LA FORCE MADAME DURAND, MADAME D’AUNEUIL, Contes, éd. crit. Raymonde Robert, Paris, Champion, 2005, pp. 776.

1 È questo il secondo volume della Bibliothèque des Génies et des Fées dove sono raccolte tutte le fiabe scritte da donne alla fine del XVII secolo che si mescolano cronologicamente a quelle di Madame d'Aulnoy (raccolte nel primo volume) e a quelle di Madame de Murat (che saranno inserite nel terzo).

2 Raymonde Robert segue quasi puntualmente lo schema già adottato per Madame d'Aulnoy: una breve Introduzione generale, seguita da una bibliografia generale (sulla scrittura femminile nel Seicento, sui contes de fées, sulla letteratura popolare e sui dizionari utilizzati), a cui segue l'edizione di tutte le fiabe delle autrici in questione. L'edizione dei contes di ogni autrice è preceduta da alcune Notices (la biografia dell'autore e le informazioni relative ad ogni conte, e da una bibliografia specifica). Tutti i contes, modernizzati come quelli di Madame d'Aulnoy nel primo volume, sono annotati e, alla fine, segue il riassunto di ogni novella, l'indice dei personaggi principali e quello delle illustrazioni, che decorano il volume stesso. L'utilità dei riassunti - di cui all'inizio non si comprendeva molto bene la funzione - diventa più evidente a mano a mano che l'edizione progredisce, poiché essi ci permetteranno di fissare rapporti fra la struttura e la tematica di una novella e l'altra, attraverso la progressione del tempo e la diversità degli autori. 